\title{
The Development of Contextual Inquiry-Based Student Worksheet to Enhance Higher Order Thinking Skills for the Topic of Water Microbiology
}

\author{
Yusnita Anwar Nasution ${ }^{1)}$ \\ ${ }^{1}$ Student of Postgraduate Program of Biology Education \\ Universitas Negeri Medan \\ Medan, Indonesia
}

\author{
Tumiur Gultom ${ }^{2}$ \\ ${ }^{2}$ Lecturer of Postgraduate Program of Biology Education, \\ Universitas Negeri Medan \\ Medan, Indonesia
}

\author{
Hasruddin $^{2)}$ \\ ${ }^{2}$ Lecturer of Postgraduate Program of Biology Education, Universitas \\ Negeri Medan \\ Medan, Indonesia
}

\begin{abstract}
The aim of this study was to find out students' higher order thinking skills after the implementation of a contextual inquiry-based student worksheet occurred. This study was conducted by applying a quasi-experimental method for the students of Biology Education, Universitas Negeri Medan. Samples were taken by simple random sampling technique. The experimental group was taught by a contextual inquiry-based student's worksheet, while the control group was taught by a conventional (traditional) student worksheet. The data collection was employed by pretest-posttest, using an essay test of higher order thinking skill for the topic of water microbiology. The results of data analysis used a student t-test for the post-test score of both groups, in which the results gave a value $\left(t_{\text {value }}=0.144 ; p=\right.$ 0.000 ) was $0.000<0.05$. It showed that there was a significant difference between experimental group and control group as well.
\end{abstract}

Keywords - Student Worksheet, Contextual Inquiry, High Order Thinking.

\section{INTRODUCTION}

Education is a process that has been designed and arranged systematically in order to stimulate growth, and development, to increase ability and skill, intelligence and character establishment, and also a positive value and attitude for every citizen in order to achieve the goals of education. Education enables students to get the opportunities, hopes, and knowledges in order to be living well, in which hopes and opportunities are depending on the quality of education that has been achieved. A qualified education certainly involve students to learn more active and aims to transform the values for students in passing through lives [1].

A learning process plays a vital role in yielding and creating the quality of educational graduate. The most important thing that needs more attention from stakeholder is to create a qualified education. The aspects that merely influence in creating a ualified learning instruction, namely: 1) professional and qualified lecturers in accordance with the Act of Teacher and Lecturer; 2) the use of fascinating and varied learning methods; 3) students' positive learning attitudes; and 4) the use of appropriate learning media in the learning process [2]. Learning sources play some important roles in a more effective and efficient learning process. It is explicitly affirmed by Association for Educational Communications and Technology [3], that learning sources are everything or resources that can be used by teachers, either used by separately or in sheaf, for the importance of learning with the purpose of improving learning efficiency.

One of the factors that can support students' self independence in learning is the availability of adequate learning sources. Textbook is one of the learning sources that can be used by students in order to seek information about the materials that is being learned. Eventhough the textbooks can be obtained easily by students, yet it is not completely able to support students' comprehension in the learning materials [4].

The selection of a learning sources refers to the formulation that exists in a syllabus. A learning source is including a reference, environment, media, informant, instrument and material that is written in an operational way [5]. Media is a means of communication that transmits a message and stimulate students' minds, feelings and skills so that it can encourage the more effective and efficient learning process [6]. The learning media are supporting tools that carries out the learning activities, by this a learning media is expected to be able to make students understand the learning materials, and one of the learning media that is frequently used is a student worksheet.

Microbiology is one of the obligatory courses for undergraduate students of Biology Education, Universitas Negeri Medan. One of the subject materials in microbiology is water microbiology, microbiology is also a course with practical work. An experimental activity is an instruction that involves students in a practical work of an experiment with the aid of student worksheet, so in the learning activity needs student worksheet that can activate students in learning. Student worksheet can be a learning source or media that depends on learning activity which is designed, a contxtual 
inquiry refers to students' activities where they develop knowledge and comprehension of scientific idea as well as the understanding on how scientists study a nature [7].

Based on the results of interview transcription and questionairre filling of needs identification with a microbiology lecturer, known that students require a worksheet. The results of interview from lecturer stated that student worksheet that has been made this now is only containing materials, working procedures, and exercises, so it was not completely training high order thinking specifically. According to [8] to facilitate students in making a parctical work, so the practice should be guided with the use of worksheet.

We all know that student is an individual who exists in an intellectual improvment with deeper thoughts, so the worksheet is highly required and exercises can train every student in developing their higher order thinking skill.

The study of [9], stated that the development of guided inquiry-based learning module could enhance students' higher order thinking skills. The study of [10], stated that the tools of microbiology learning based contxtual could enhance students' higher order thinking skills as well. Inquiry refers to several ways where scientists studied a nature and proposed explanations based on evidents from their works. A contextual inquiry also refers to stdents' activities where they develop knowledge and comprehension of a scientific idea as well an understanding on how scientists studied a nature. Inquiry is a part of a contextual learning, an inquiry (to inquire) is the third component of main components in a contextual learning. The steps in learning process with the use of a contextual inquiry approach, that are: to make an orientation, to formulate problems, to formulate hypotheses, to collect data, to test hypotheses and to formulate a conclusion.

A thinking skill requires a skill to recall and understand, hence a recall skill is the most important thing in developing thinking skill. In this case, someone who has not possessed skills to recall and understand, they also has not possessed skills to think rationally and logically. On the contrary, someone's thinking skill has been absolutely intertwined by recalling and understanding skill as well [11].

Higher Order Thinking Skills (HOTS) is a thinking activity that involves a higher level of cognitive aspect from Bloom's Taxonomy. However, the experts defined a higher-order thinking in a different way. According to Benjamin Bloom, a higher-order thinking is an abstract skill in a cognitive domain, that are analysis, synthesis, and evaluation. [12], solidified Bloom's Taxonomy to be four main levels. Four main levels of cognition based on Newcomb and Trefz are recall, information processing, creation and evaluation. Newcomb and Trefz classified recall and information processing into lower-order thinking and higher-order thinking as well. [13] made a fundamental tranformation on Bloom's Taxonomy by changing two last steps on Bloom's Taxonomy, that are evaluation and creation.

Higher-order thinking is a thinking skill in a higher level rather than it is memorizing facts or saying something to someone just exactly as it is said to us. [14] suggested that higher order thinking skill is a thinking process that involves a mental activity on the effforts of exploration complex, reflective and creative experiences, that is employed conciously to achieve goal, that is to obtain knowledge comprises analytical, synthetical and evaluative thinking skills.

Thus, higher order thinking skill will occur when someone relates a new information with another information that has been kept inside memory and interrelate or rebuild as well as develop those informations to achieve a goal or to discover a solution of the unsolved situation.

\section{LITERATURE REVIEW}

Worksheet is a learning source that facilitates students in the learning activity. A worksheet consists of experimental worksheet and non experimental worksheet. An experimental worksheet includes a worksheet that accomodates a pratical work direction using instruments and materials. A non experimental worksheet includes a worksheet that accomodates a text that strives for students to conduct discussion in a learning material [15].

Student worksheets includes printed media of printed technology development, that are books and visual materials [16]. Student worksheet is one of learning sources that can be developed by lecturer, who plays a role as a facillitator in the learning activity. Student worksheet can be arranged and developed in accordance with any condition and situation that will be overcome [17]. Student worksheet is also a learning media, because it can be used simultaneously with other learning sources. Student worksheet can be a learning source or media depends on the design of the learning activity.

According to [18], inquiry-based instruction is an inquiry learning that can develop a way of thinking scientifically that positions students as a learner in solving problems and obtaining an investigative knowledge, so it can understand science concepts. An inquiry-based instruction gives opportunities on students to be engaged more actively in the learning activity. An instruction by inquiry according to [19], "Scientific inquiry extends beyond the development of process skills such as observing, inferring, classifying, predicting, measuring, questioning, interpreting and analyzing data. Scientific inquiry includes the traditional science processes, but also refers to the combining of these processes with scientific knowledge, scientific reasoning and critical thinking to develop scientific knowledge".

This inquiry is a part of contextual instruction. Inquiry (to inquire) is the third component of main components in a contextual instruction. According to [20], a contextual inquirybased learning process comprises orientation, problem formulation, hypotheses formulation, data collection, hypotheses testing and conclusion. It can be suggested that inuiry is a part of contextual learning component, in fact the application of an inquiry learning method is varied depends on any situation and condition as well.

According to [21], a contxtual inquiry is a varied process and comprises the activities to observe, to formulate relevant questions, to evaluate books and other sources of information 
critically, to design an investigation, to review what is known, to conduct experiments with the use of instruments to obtain data, to analyze and interpret data, and also to make prediction and communicate the results. An inquiry refers to several ways where scientists studied a nature and proposed the explanations based on evidence from their works. A contextual inuiry also refers to students' activities where they develop their knowledge and comprehension of scientific idea as well as understanding on how scientists studied a nature.

According to [22], thinking skill requires a skill to recall and understand, hence the skill of recall is the most important thing in developing thinking skills. In this case, someone who has not possessed skills to recall and understand, they also has not possessed skills to think rationally and logically. On the contrary, someone's thinking skill has been absolutely intertwined by recalling and understanding skill as well.

According to [23], in the learning activity, students are not only obtaining the loads of knowledge, and keep them stacked into their minds, if they want to learn effectively. Students need to understand what they have learned and know when, where and how to use those knowledges. The learning effectivenes is extremely determined by knowledge. A dominant mental proses, in this case is "to think".

\section{METHOD}

This study was conducted in the Laboratory of Biology, Universitas Negeri Medan in Jln. William Iskandar Pasar V Medan Estate - Postal Code 20221. It was conducted from April to June 2017.

The study was a quasi-experimental method with the population of all the sixth semester students at Universitas Negeri Medan, indonesia. The samples consisted of two classes, Class A was classified into the experimental group, while Class $\mathrm{C}$ was classified into the control group, taken by simple random sampling. The learning instruction for the experimental group used a contextual inquiry-based worksheet for the topic of water microbiology, meanwhile the control group used a conventional worksheet.

The instrument of higher order thinking skills was the essay test consisting of 8 items. It was validated by 3 experts, furthermore the test could be used as a research instrument.

The data testing of the students' pretests and post-tests was applied the normality test and hypotheses test by using spss version 22.0 .

\section{RESULTS AND DISCUSSION}

\subsection{Results of Instrument Testing}

The instrument could be used if it was initially validated by professional experts. The content and construct validaty were validated by 3 expertise lecturers. The results of validation showed that the essay test could be used as the research instrument.

\section{Pretest}

Pretests were given to students before the treatment applied to find out the initial score of higher order thinking skills for both groups. The average score of higher order thinking skills pretests could be seen in Table 1 .

\begin{tabular}{crccc}
\multicolumn{5}{c}{ TABLE 1. The Average Score of Pretests } \\
\hline Group & $\begin{array}{c}\text { Average } \\
\text { Score of } \\
\text { Pretest }\end{array}$ & $\begin{array}{l}\text { Minimu } \\
\text { m Score }\end{array}$ & $\begin{array}{c}\text { Maximum } \\
\text { Score }\end{array}$ & SD \\
\hline Experimental & 45.72 & 32.50 & 62.50 & 7.87 \\
Control & 44.34 & 32.50 & 60.00 & 7.35 \\
\hline
\end{tabular}

From Table 1, it was clearly known that experimental group had an average score of 45.72, minimum score of 32.50 , maximum score of 62.50 , and standard deviation of 7.87 . The control group had an average score of 44.34, minimum score of 32.50, maximum score of 60.00, and standard deviation of 7.35. Subsequently, the data was processed by the normality test. The normality test could be seen in Table 2 .

TABLE 2. Normality Test on Pretest Score

\begin{tabular}{cccc}
\hline Group & \multicolumn{2}{c}{$\begin{array}{c}\text { Normality Test } \\
\text { Kolmogorov- }\end{array}$} & Descr. \\
& \multicolumn{2}{c}{ Smirnov } & \\
\cline { 2 - 3 } & Statistic & Significant & \\
\hline Experimental & 0.118 & 0.095 & Normal \\
Control & 0.108 & 0.093 & Normal
\end{tabular}

From Table 2, it was clearly known that the data of both groups were normally distributed on the significance level of $>$ 0.05 . Subsequently, it was tested by the student t-test on pretest score for both groups. The results of data by a student t-test could be seen in Table 3 .

\begin{tabular}{cccccc}
\multicolumn{6}{c}{ TABLE 3. Student t-test on Pretest Scores } \\
\hline Group & $\begin{array}{c}\text { Avera } \\
\text { ge } \\
\text { Score }\end{array}$ & SD & Sig & $\boldsymbol{\alpha}$ & Descr. \\
(2 -tailed) & & \\
\hline $\begin{array}{c}\text { Experi } \\
\text { mental }\end{array}$ & 45.72 & 7.87 & & & $\begin{array}{c}\text { There was } \\
\text { no a } \\
\text { significant } \\
\text { difference }\end{array}$
\end{tabular}

Control

From Table 3, it was obviously known that both groups had a homogenous average score of pretest, in which results of the test gave a value of 0.353 , it could be concluded that there were no significant differences.

\section{Post-test}

Post-tests were conducted after experimental group used a contextual inuiry-based student worksheet and control group used a conventional worksheet. The average score of higher order thinking skill pretests could be seen in table 4 . 
TABLE 4. The Average Score of Post-test

\begin{tabular}{ccccc}
\hline Group & $\begin{array}{c}\text { Averag } \\
\text { e Score } \\
\text { of } \\
\text { Pretest }\end{array}$ & $\begin{array}{c}\text { Minimum } \\
\text { Score }\end{array}$ & $\begin{array}{c}\text { Maximum } \\
\text { Score }\end{array}$ & SD \\
\hline Experimental & 72.34 & 57.50 & 85.00 & 7.87 \\
Control & 66.62 & 52.50 & 85.00 & 6.77
\end{tabular}

From Table 2, it was clearly known that experimental group had an average score of 72.34, minimum score of 57.50, maximum score of 85.00, and standard deviation of 7.87. The control group had an average score of 66.62 , minimum score of 52.50, maximum score of 85.00, and standard deviation of 6.77. Subsequently, the data was processed by the normality test. The normality test could be seen in Table 5 .

TABLE 5. Normality Test on Post-test Score

\begin{tabular}{cccc}
\hline Group & \multicolumn{2}{c}{$\begin{array}{c}\text { Normality Test } \\
\text { Kolmogorov- } \\
\text { Smirnov }\end{array}$} & Descr. \\
& \multicolumn{2}{c}{ Significant } \\
\cline { 2 - 3 } & Statistic & Significant & Signis \\
\hline Experimental & 0.117 & 0.098 & Normal \\
Control & 0.113 & 0,113 & Normal \\
\hline
\end{tabular}

From Table 5, it was known that the data of both groups were normally distributed on the significance level of $>0.05$. Subsequently, it was tested by the student t-test on post-test score for both groups. The results of data by a student t-test could be seen in Table 6 .

\begin{tabular}{llcccc}
\multicolumn{6}{l}{ TABLE 6. Student t-test on Post-test Score } \\
\hline Group & $\begin{array}{l}\text { Average } \\
\text { Score of } \\
\text { Post-test }\end{array}$ & SD & $\begin{array}{c}\text { Sig } \\
\text { (2-tailed) }\end{array}$ & $\boldsymbol{\alpha}$ & Descr \\
\hline Experi & 72.34 & 7.67 & & & \\
mental & & & 0.000 & 0.05 & $\begin{array}{c}\text { There } \\
\text { was a } \\
\text { signif } \\
\text { icant } \\
\text { differ } \\
\text { ence }\end{array}$
\end{tabular}

Control $\quad 66.62 \quad 6.77$

From Table 6 , it was known that t-test (2-tailed) on posttest score of both groups, results of the test gave a value of 0.000 , it could be concluded that there was a significant difference. The difference of students' higher order thinking skills using a contextual inquiry-based worksheet and without using a contextual inquiry-based worksheet (conventional) were depicted in Figure 3.1

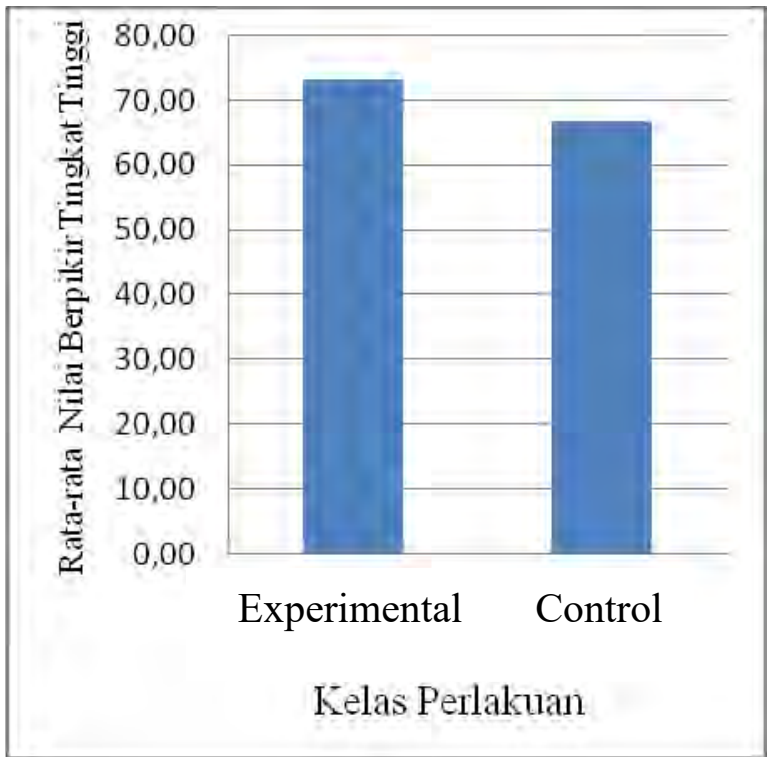

Fig 3.1. The Comparison of Higher-Order Thinking Average Score for Experimental and Control Group

\section{Discussion}

Based on the results of hypothetical testing for higherorder thinking on pretest, it was known that there was no a significant difference on students' higher-order thinking skills which was taught by a contextual inquiry-based worksheet and taught without the use of a contextual inquiry-based worksheet (conventional) for students of Biology Education, Universitas Negeri Medan $\left(\mathrm{t}_{\mathrm{value}}=0.932 ; \mathrm{p}=0.353\right)$. The average score of students' higher order thinking skills taught by the use of a contextual inquiry-based worksheet was (45.72 \pm 7.87$)$ significantly higher than taught by without the use of a contextual inquiry-based worksheet (conventional) (44.34 \pm 7.35).

Based on the results of hypothetical testing for students' higher order thinking skills on post-test was clearly known that there was a significance difference of students' higher order thinking skills taught by the use of a contextual inquirybased worksheet and taught by without the use of a contextual inquiry-based worksheet (conventional) for the students of Biology Education, Universitas Negeri Medan $\left(\mathrm{t}_{\mathrm{value}}=4.001 ; \mathrm{p}\right.$ $=0.000)$. The average score of students' science process skills using a contextual inquiry-based worksheet was (75.34 \pm 7.87$)$ significantly higher than taught without the use of a contextual inquiry-based worksheet (conventional) (66.62 \pm 6.77).

In this case, it could be concluded that there was a significant difference of students' higher order thinking skills who were taught by a contextual inquiry-based worksheet for the topic of water microbiology than students who were not taught by a contextual inquiry-based worksheet (conventional) of Biology Education, Universitas Negeri Medan. A higher-order thinking was very important for every student as a foundation to apply a scientific method in developing science and obtaining a new knowledge or developing their own knowledge as well.

It would be due to the contextual inquiry was closely related with the classroom activity for a certain learning 
purpose that would be achieved, involving the original data analysis, encouraging students' communication and collaborating with constructive learning process, involving the use of materials' skills and cooperating in the application of science concepts for the context of direct instruction.

This was in line with the study of [24], stated that the development of contextual-based microbiology learning tools could enhance students' higher order thinking skills. [25], stated that inquiry learning model could increase students' learning outcomes for the topic of fungi in the tenth grade of SMK Negeri 1 Rambah, Academic Year 2014/2015. The study of [26] stated that the development of guided inquirybased learning module could improve students' higher order thinking skill. [27] stated that through the processes of problem solving could enhance students' higher order thinking skills, where problem solving and guided inquiry were classified into constructivist learning models. It means that the constructivist learning approaches were very effective to enhance students' higer order thinking skills

Higher order thinking skill was defined as the use of thinking more widely to find a new challenge. This higher order thinking skill wanted someone to apply the new information or other previous knowledge and then manipulate the information to reach the possibility of an answer in a new situation [28].

\section{CONCLUSION}

Based on the results of the study, it could be concluded that: there was a difference of students' higher order thinking skills with the use of a contextual inquiry-based student worksheet and without the use of a contextual inquiry-based student worksheet (conventional) for the topic of water microbiology.

Based on the tests that have been employed and conclusion aformentioned, any suggestion were highly required, as follows: (1) Student worksheet was arranged in accordance with the contextual inquiry learning instruction. Hence, the student worksheet could be used as a guidance of additional practical work, so it was able to gives students some more positive feedbacks; (2) In order to have a more meaningful and deep insight for the perfection of this student worksheet, so the contextual inquiry-based worksheet for the topic of water microbiology with a broader scope to get more maximum results; and (3) The results of this research and developmental study was probably influenced by any uncontrollable factors, so it needs a much further research for more materials and samples and for more maximum results as well.

\section{ACKNOWLEDGMENTS}

It was acknowledged to Direktorat Riset dan Pengabdian pada Masyarakat (Directoriate of Research and Service on Society), and Direktorat Jenderal Penguatan Riset dan Pengembangan Kementrian Riset, Teknologi, dan Pendidikan Tinggi (General Directoriate of Research Reinforcement and Development, Ministry of Research, Technology and High Education, in accordance with the Research Contract, No. 045A/UN33.8/LL/2017.

\section{REFERENCES}

[1] Sani, R. A. (2014). Pembelajaran Saintifik untuk Implementasi Kurikulum (2013). Jakarta: PT Bumi Aksara.

[2] Winarno. 2009. Teknik Evaluasi Multimedia Pembelajaran. Yogyakarta: Genius Prima Media.

[3] Depdiknas. (2008). Panduan Pengembangan Buku Ajar. Jakarta: Dapertemen Pendidikan Nasional.

[4] Rahmi, Villia Anggraini, dan Melisa. 2014. Pengembangan Lembar Kerja Mahasiswa Berbasis Problem Based Learning pada Perkuliahan Persamaan Difrensial Biasa. Prosiding Seminar Nasional Sains dan Pendidikan Sains IX, Fakultas Ni'mah S / LENTERA Jurnal Ilmiah Kependidikan Vol. 11(2): $60-65$

[5] Daryanto, (2014) Pembelajaran Tematik, Terpadu, Terintegrasi (Kurikulum 2013). Jogjakarta: Gava Media.

[6] Arsyad. (2004). Media Pembelajaran. Jakarta: Raja Grafindo Persada.

[7] Semiawan, C. (1992). Pendekatan Keterampilan Proses Sains.Jakarta: Gramedia.

[8] Rohaeti (2006). Pengembangan Lembar Kerja Siswa (LKS) Mata Pelajaran Sains. Kimia untuk SMP Kelas VII, VIII dan IX. Artikel Penelitian, Yogyakarta: FMIPA UNY.

[9] Wafiroh, M. 2017. Pengembangan Modul Pembelajaran Berbasis Inkuiri Terbimbing untuk Meningkatkan Kemampuan Berpikir Tingkat Tinggi. Prosiding SNPF ISSN 2527-6670. Madiun: Universitas PGRI Madiun.

[10] Hasruddin., Fauziyah H., Mahmud. (2016) . Pengembangan Perangkat Pembelajaran Mikroiologi Berbasis Kontekstual untuk Meningkatkan Kemampuan Berpikir Tingkat Tinggi Mahasiswa. Proceeding Biology Education Conference (ISSN: 2528-5742), Vol 13(1) 2016: 509-514.

[11] Sanjaya, W. (2009). Strategi Pembelajaran Berorientasi Standar Proses Pendidikan. Jakarta: Prenada Media Group.

[12] Newcomb, L. H.,\& Trefz, M. K. (1987). Levels of Cognition of Student Tests and Assignments in The College of Agriculture at The Ohio State University. Proceedings of The Fourteenth Annual National Agricultural Education Research Meeting, Las Vegas, NV.

[13] Anderson, L.W., dan Krathwohl, D.R. (2001). A Taxonomy For Learning Teaching, and Assesing: A Revision of Blomms Taxonomy of Education Objektives. New York: Addison Wesley Lonman Inc.

[14] Wardana, N. 2010. Pengaruh Model Pembelajaran Berbasis Masalah dan Ketahanmalangan Terhadap Kemampuan Berpikir Tingkat Tinggi dan Pemahaman Konsep Fisika. Diperoleh 28 Januari 2012 dari http://jurnal.pdii.lipi.go.id/admin/jurnal/621016251635_1858-4543.pdf.

[15] Widjajanti. (2012). Pengembangan Lemabar Kerja Siswa Berbasis Keterampilan Proses Sains Pada Materi Pencemaran Lingkungan Kelas VIII SMP. Journal Bioedukasi, 5 (2): 23-30.

[16] Rehulina. (2013). Pengembangan Lembar Kerja Siswa Berbasis Inquiry untuk Pembelajaran Biologi SMA Kelas XII Semester I. Tesis tidak diterbitkan. Medan: Pascasarsajana unimed.

[17] Widjajanti, Endang LFX. (2008). Kualitas lembar kerja siswa. Makalah ini disampaikan dalam Kegiatan Pengabdian pada Masyarakat, FMIPA UNY, 22. Online. http://staff.uny.ac.id/system/files/pengabdian/ endangwidjajanti-lfx-ms-dr/kualitas-lks.pdf. (diakses tanggal 11 Desember 2016).

[18] Kurniawati, I. D., Wartono, dan D. Markus. (2013). Pengaruh Pembelajaran Inkuiri Terbimbing Integrasi Peer Instruction Terhadap 
Penguasaan Konsep dan Kemampuan Berpikir Kritis Siswa. Jurnal Pendidikan Fisika Indonesia. Vol.10: 36-46.

[19] Lederman, N. G., J. S. Lederman, dan A. Antink. (2013). Nature of science and scientific inquiry as contexts for the learning of science and achievement of scientific literacy. International Journal of Education in Mathematics Scienceand Technology. Vol. 1 (3): 138-147.

[20] Sanjaya, W. (2009). Strategi Pembelajaran Berorientasi Standar Proses Pendidikan. Jakarta: Prenada Media Group.

[21] Lotter, C., Harwood W.S., Bonner, J.J. (2006). The Influence of Core Teaching Conceptions on Teachers' Use of Inquiri Teaching Practices. Journal Of Resaearch In Science Teaching. 10(102): 1-5.

[22] Sanjaya, W. (2009). Strategi Pembelajaran Berorientasi Standar Proses Pendidikan. Jakarta: Prenada Media Group.

[23] Amir, T,M. (2009). Inovasi Penididkan Melalui Problem Based Learning. Jakarta: Kencana.

[24] Hasruddin., Fauziyah H., Mahmud. (2016) . Pengembangan Perangkat Pembelajaran Mikroiologi Berbasis Kontekstual untuk Meningkatkan Kemampuan Berpikir Tingkat Tinggi Mahasiswa. Proceeding Biology Education Conference (ISSN: 2528-5742), Vol 13(1): 509-514.

[25] Heriyanto., Lestari., R., Riharji, R. (2015). Pengaruh Model Pembelajaran Inquiri terhadap Hasil Belajar Siswa pada Materi Jamur di Kelas X SMK Negeri 1 Rambah Tahun Pembelajaran 2014/2015. Rambah: Program Studi Pendidikan Biologi Universitas Pasir Pengaraian.

[26] Wafiroh, M. 2017. Pengembangan Modul Pembelajaran Berbasis Inkuiri Terbimbing untuk Meningkatkan Kemampuan Berpikir Tingkat Tinggi. Prosiding SNPF ISSN 2527-6670. Madiun: Universitas PGRI Madiun.

[27] Yulinda, Ratna. (2011). Hasil Belajar, Kinerja, dan Keterampilan Berpikir TingkatTinggi Siswa SMA pada Pembelajaran Konsep Jenis dan Daur Ulang Limbahmelalui Proses-Proses Problem Solving. Tesis. Pascasarjana PendidikanBiologi. Banjarmasin. Tidak Dipublikasikan.

[28] Quittadamo, I.J., Kurtz, M. (2008). Learning to Improve: Using Writing to Increase Critical Thinking Performace in General Educational Biology. Life Science Educational. 6(2): 140-154.

[29] Heong, Y.M., Othman, W.D., Md Yunos, J., Kiong, T.T., Hassan, R., \& Mohamad, M.M. 2011. The Level of Marzano Higher Order Thinking Skills Among Technical Education Students. International Journal of Social and Humanity, Vol. 1 (2): 121-125. 